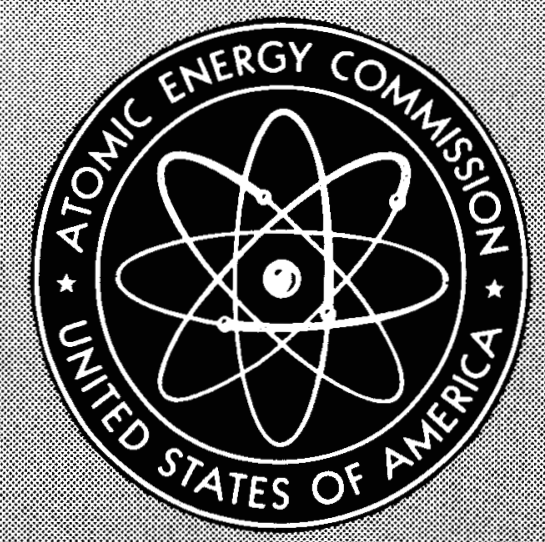

GA-4138

\title{
IRRADIATION BEHAVIOR OF BeO-UO, FUEL AS A FUNCTION OF FUEL-PARTICLE SIZE
}

By

Dale E. Johnson

R. G. Mills

April 16, 1963

General Atomic Division

General Dynamics Corporation

San Diego, California 


\section{DISCLAIMER}

This report was prepared as an account of work sponsored by an agency of the United States Government. Neither the United States Government nor any agency Thereof, nor any of their employees, makes any warranty, express or implied, or assumes any legal liability or responsibility for the accuracy, completeness, or usefulness of any information, apparatus, product, or process disclosed, or represents that its use would not infringe privately owned rights. Reference herein to any specific commercial product, process, or service by trade name, trademark, manufacturer, or otherwise does not necessarily constitute or imply its endorsement, recommendation, or favoring by the United States Government or any agency thereof. The views and opinions of authors expressed herein do not necessarily state or reflect those of the United States Government or any agency thereof. 


\section{DISCLAIMER}

Portions of this document may be illegible in electronic image products. Images are produced from the best available original document. 


\section{LEGAL NOTICE}

This report was prepared as an account of Government sponsored work. Neither the United States, nor the Commission, nor any person acting on behalf of the Commission:

A. Makes any warranty or representation, expressed or implied, with respect to the accuracy, completeness, or usefulness of the information contalned in this report, or that the use of any information, apparatus, method, or process disclosed in this report may not infringe privately owned rights; or

B. Assumes any liabilities with respect to the use of, or for damages resulting from the use of any information, apparatus, method, or process disclosed in this report.

As used in the above, "person acting on behalf of the Commission" includes any employee or contractor of the Commission, or employee of such contractor, to the extent that such employee or contractor of the Commission, or employee of such contractor prepares, disseminates, or provides access to, any information pursuant to his employment or contract with the Commission, or his employment with such contractor.

This report has been reproduced directly from the best available copy.

Printed in USA. Price $\$ 0.75$. Available from the Office of Technical Services, Department of Commerce, Washington 25, D. C. 
GENERAL ATOMIC

DIVISION OF

GENERAL DYNAMICS

JOHN JAY HOPKINS LABORATORY FOR PURE AND APPLIED SCIENCE

P.O. BOX 608. SAN DIEGO 12. CALIFORNIA

GA -4138

METALS, CERAMICS, AND MATERIALS

IRRADIATION BEHAVIOR OF BeO-UO 2 FUEL AS A FUNCTION OF FUEL-PARTICLE SIZE

by

Dale E. Johnson and R. G. Mills

Presented at the American Ceramic Society Symposium on Ceramic Materials for Nuclear Power and Space Applications, Pittsburgh, Pennsylvania, April 28 through May 2, 1963.

U.S. Atomic Energy Commission

Contract AT(04-3)-187

April 16, 1963 
$\theta$ 


\section{ABSTRACT}

One capsule containing $\mathrm{BeO}-30 \mathrm{vol}-\% \mathrm{UO}_{2}$ fuel pellets was irradiated in the Materials Testing Reactor to a uranium burnup of approximately 30,000 Mwd/ton. The results of a microscopic examination and of physical measurements that were made during the hot-cell examination of the capsule are described. Some of the implications of these observations are discussed. 


\section{INTRODUCTION}

Many of the factors associated with the use of dispersion-type reactor fuel materials have been discussed in the literature. ${ }^{1-4}$ Some of the se factors are (1) increases in the specific power capabilities of the fuel owing to the increased thermal conductivity of the fuel-matrix composite, (2) improved mechanical performance of the composite owing to isolation of the regions in the matrix that are affected by fission-fragment recoils, and (3) reduced fission-product release due to diffusion owing to the decreased average fuel temperature relative to that for solid fuel compounds such as $\mathrm{UO}_{2} \cdot$ The release of fission products is also minimized by isolation of the fuel particles within an envelope of "impermeable" matrix material.

Some of the early results reported by Yeniscavich and Bleiberg ${ }^{5}$ on the use of $\mathrm{UO}_{2}$ dispersed in $\mathrm{BeO}$ as a reactor fuel indicated that dimensional changes and fission-gas release were substantially greater in fuel bodies that contained the $\mathrm{UO}_{2}$ in the form of a dispersion of fine (0 to $50 \mu$ ) particles than in fuel bodies that contained the $\mathrm{UO}_{2}$ in the form of a dispersion of coarse $(\sim 150 \mu)$ particles. However, the se observations were made on fuel bodies that had been irradiated at relatively low average temperatures $\left(440^{\circ}\right.$ to $\left.500^{\circ} \mathrm{C}\right)$.

In order to determine if the results obtained by Yeniscavich and Bleiberg are representative for high-temperature applications of similar fuels, a program was undertaken at General Atomic as a part of the Experimental Beryllium Oxide Reactor Program to study the relative hightemperature performance of $\mathrm{BeO}-\mathrm{UO}_{2}$ fuel materials containing $30 \mathrm{vol}-\%$ $\mathrm{UO}_{2}$ with the $\mathrm{UO}_{2}$ present in the form of fine $(<25 \mu)$ and coarse $(\sim 150 \mu)$ particles. The irradiation of two capsules containing representative fuel specimens made with the two types of particles was included in this program. The purpose of this paper is to describe the observations that were made 
during the post-irradiation examination of the $\mathrm{BeO}-\mathrm{UO}_{2}$ specimens from the first of the two irradiation capsules.

\section{MATERIALS AND EQUIPMENT}

\section{MATERIALS USED IN FABRICATION OF THE FUEL PELLETS}

The fuel pellets used in this irradiation experiment were composed of 70 vol-\% BeO-30 vol-\% $\mathrm{UO}_{2}$ and were fabricated at General Atomic. The chemical compositions of the oxide powders used in the fabrication of the fuel pellets are presented in Table I. The pellets were fabricated by drypressing in a steel die and subsequently sintering in a molybdenum-wound tube furnace, using an atmosphere of $25 \%$ hydrogen and $75 \%$ nitrogen. Following the sintering process, the pellets were ground to the required dimensions: approximately $0.4 \mathrm{in}$. in diameter and $0.5 \mathrm{in}$. long. The required uranium enrichment of 12 atom-\% U $\mathrm{U}^{235}$ was obtained by blending naturalenrichment $\mathrm{UO}_{2}$ powder and fully enriched $\mathrm{UO}_{2}$ powder.

Two types of specimens were fabricated. One type contained the $\mathrm{UO}_{2}$ in the form of a homogeneous dispersion of fine particles. Metallographic examination of a polished cross section of a typical fuel specimen indicated that the $\mathrm{UO}_{2}$ was present in the form of somewhat irregularly shaped particles with maximum dimensions of approximately $25 \mu$. The second type of fuel pellet contained the $\mathrm{UO}_{2}$ in the form of larger particles with maximum dimensions of approximately $150 \mu$. A comparison of the two types of fuel pellets (see Fig. 1) indicates that in the pellets containing coarse fuel particles, the individual particles are readily discernible by visual inspection, whereas the pellets containing the fuel in the form of fine particles have a uniform, dark-brown appearance. Figure $2 \underline{a}$ is a photomicrograph of a fine-particle fuel pellet, and Fig. 3 is a photomicrograph of a coarse-particle fuel pellet. From these figures, it may be observed that the distribution of the fuel particles in the BeO matrix was uniform. The densities of the pellets before irradiation are presented in Table II. 
Table I

COMPOSITION OF OXIDE POWDERS USED IN THE FABRICATION OF FUEL PELLETS FOR THE MGCR-9 CAPSULE

\begin{tabular}{|c|c|c|c|}
\hline & \multicolumn{3}{|c|}{ Typical Composition (ppm) } \\
\hline & $\mathrm{BeO}^{\underline{a}}$ & $\mathrm{UO}_{2}$ (Normal) $\underline{b}$ & $\mathrm{UO}_{2}\left(93.24 \% \mathrm{U}^{235}\right)^{\mathrm{c}}$ \\
\hline $\mathrm{U}$ & & $87.32 \%$ & $87.9 \%$ \\
\hline$O / U^{d}$ & & 2.16 & \\
\hline $\mathrm{BeO}$ & $99+\%$ & & \\
\hline $\mathrm{MgO}$ & 50 & 17 & 60 \\
\hline $\mathrm{Al}_{2} \mathrm{O}_{3}$ & 100 & & 70 \\
\hline $\mathrm{SiO}_{2}$ & 100 & 100 & 300 \\
\hline $\mathrm{CaO}$ & 50 & 70 & 10 \\
\hline $\mathrm{Fe}_{2} \mathrm{O}_{3}$ & 20 & 100 & 140 \\
\hline $\mathrm{Na}_{2} \mathrm{O}$ & 50 & & \\
\hline $\mathrm{Cr}$ & 10 & $<10$ & 50 \\
\hline $\mathrm{Ni}$ & 20 & $<10$ & 50 \\
\hline Co & 5 & & $<1$ \\
\hline $\mathrm{Cu}$ & 5 & $<3$ & 20 \\
\hline Mn & 10 & $<10$ & $<10$ \\
\hline $\mathrm{Li}$ & 1 & & \\
\hline B & 3 & $<0.2$ & 1 \\
\hline $\mathrm{Cd}$ & 2 & & 0.1 \\
\hline Rare earths & & & $<10$ \\
\hline $\mathrm{Pb}$ & & $<2$ & \\
\hline $\mathrm{Sn}$ & & $<2$ & $<5$ \\
\hline $\mathrm{V}$ & & $<1$ & $<10$ \\
\hline$P$ & & & $<10$ \\
\hline $\mathrm{Zn}_{\mathrm{n}}$ & & & 0 \\
\hline $\mathrm{Ba}$ & & 2 & $<10$ \\
\hline
\end{tabular}

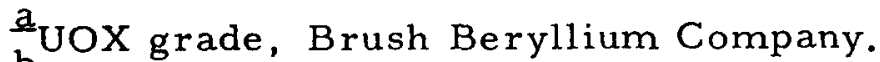

${ }^{b}$ Ceramic grade, Nuclear Materials and Equipment Corp. $\stackrel{c}{c}$ Ceramic grade, Davison Chemical Company.

d Atomic ratio of oxygen to uranium. 


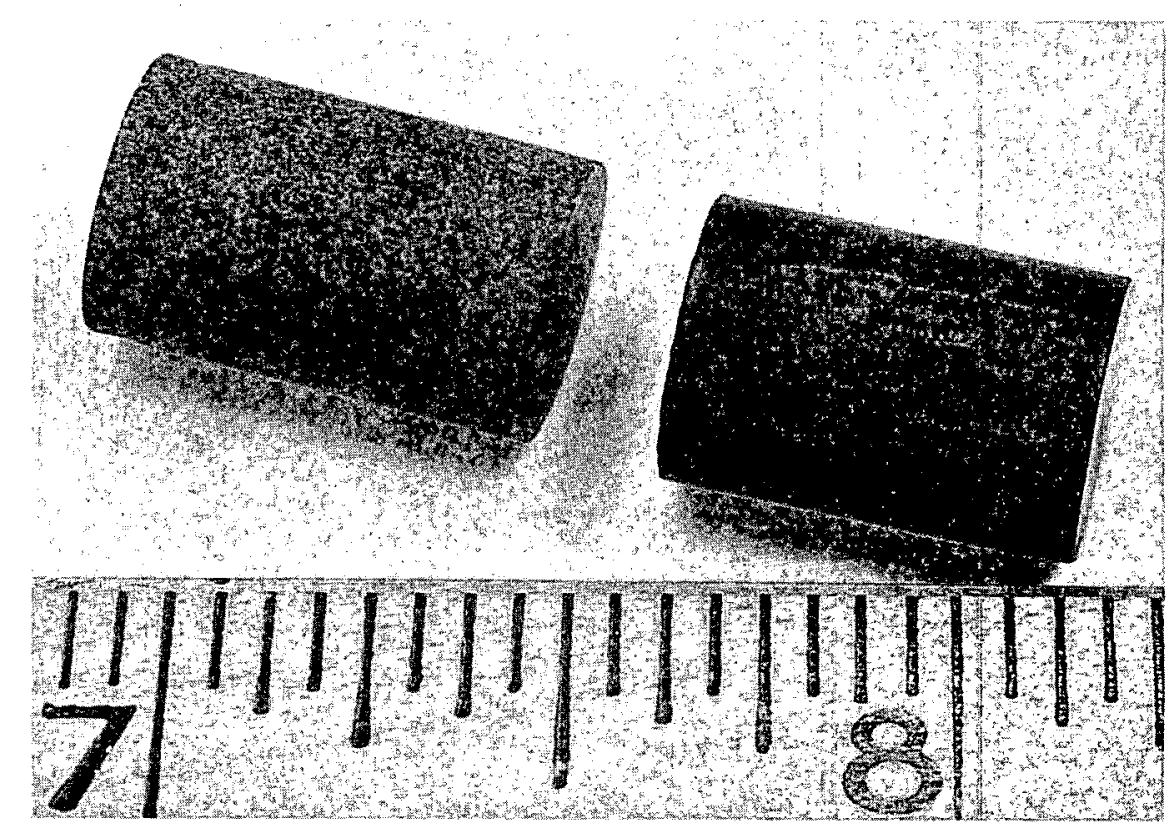

Fig. 1--Photomacrograph of typical $\mathrm{BeO}-30$ vol- $\% \mathrm{UO}_{2}$ fuel pellets used in the MGCR-9 capsule, containing coarse $\mathrm{UO}_{2}$ particles (left) and fine $\mathrm{UO}_{2}$ particles (right) 


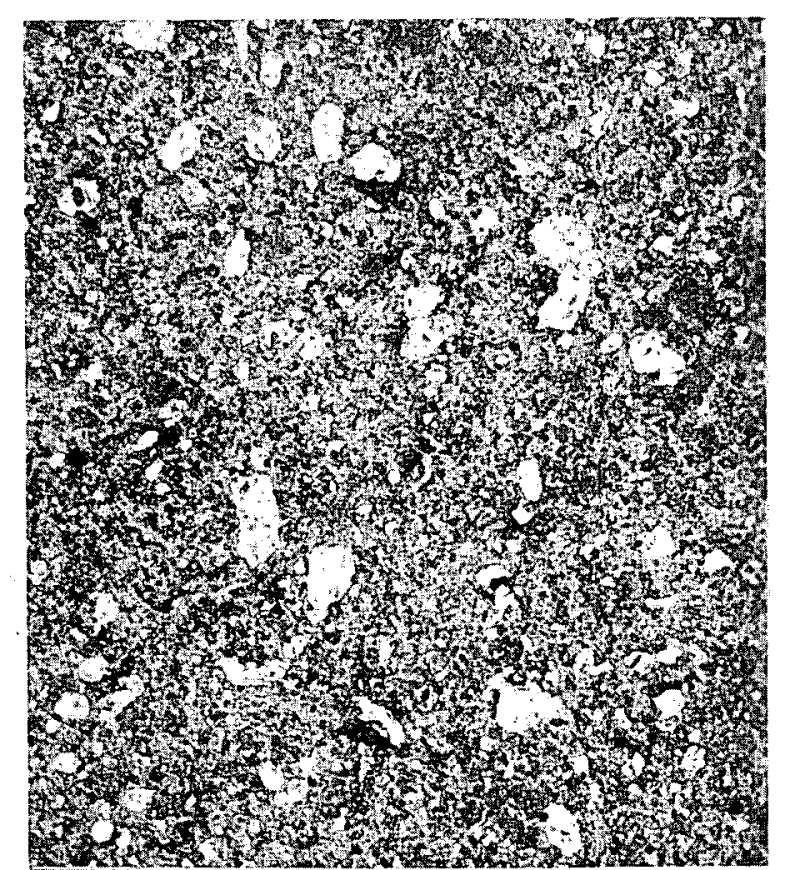

$M-754-1-2$

100

(a) As-polished cross section of a typical $\mathrm{BeO}-30 \mathrm{vol}-\% \mathrm{UO}_{2}$ fuel pellet containing fine $(<25 \mu) \mathrm{UO}_{2}$ fuel particles $(250 x)$

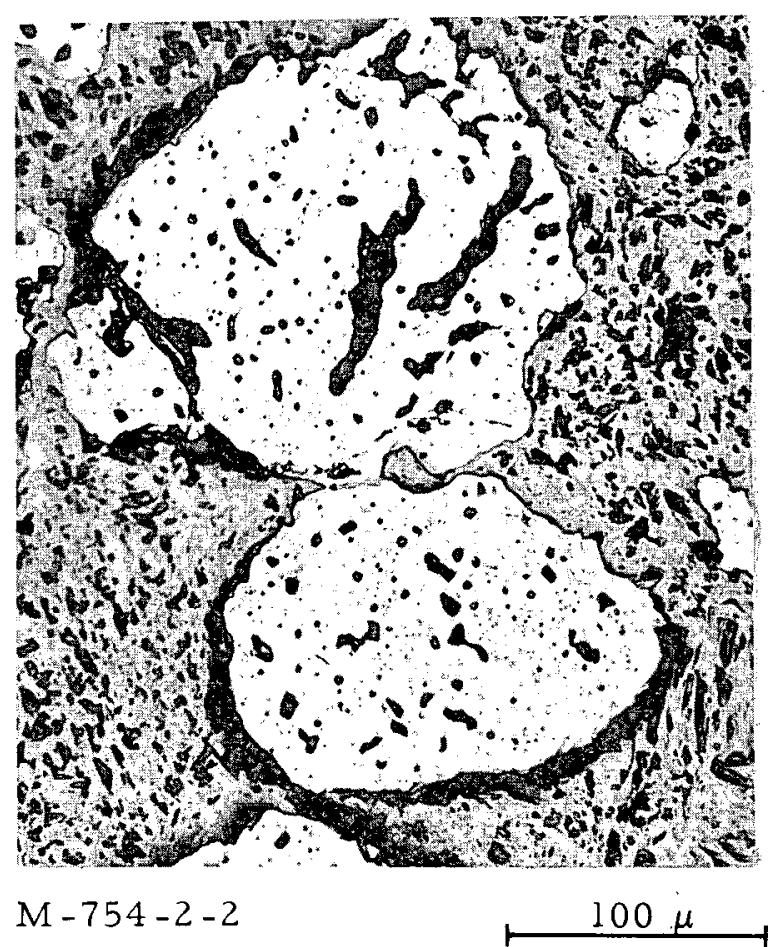

(b) As -polished cross section of a typical $\mathrm{BeO}-30$ vol $-\% \mathrm{UO}_{2}$ fuel pellet containing coarse $(\sim 150 \mu)$ $\mathrm{UO}_{2}$ fuel particles $(250 \times)$

Fig. 2--Pre-irradiation photomicrographs of typical fuel pellets used in the MGCR-9 capsule 


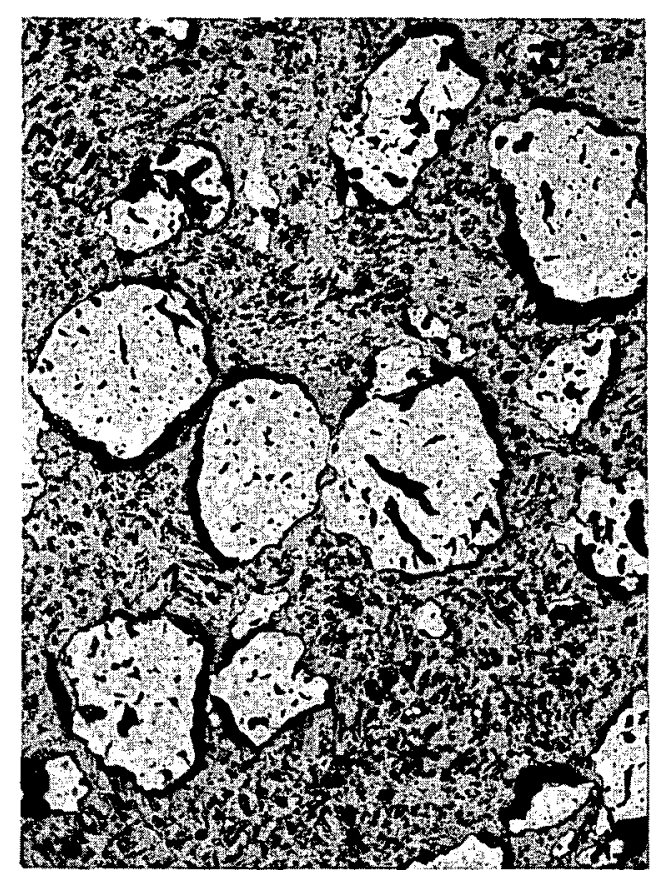

$M-754-2-1$
250

(a) As-polished cross section $(100 \times)$

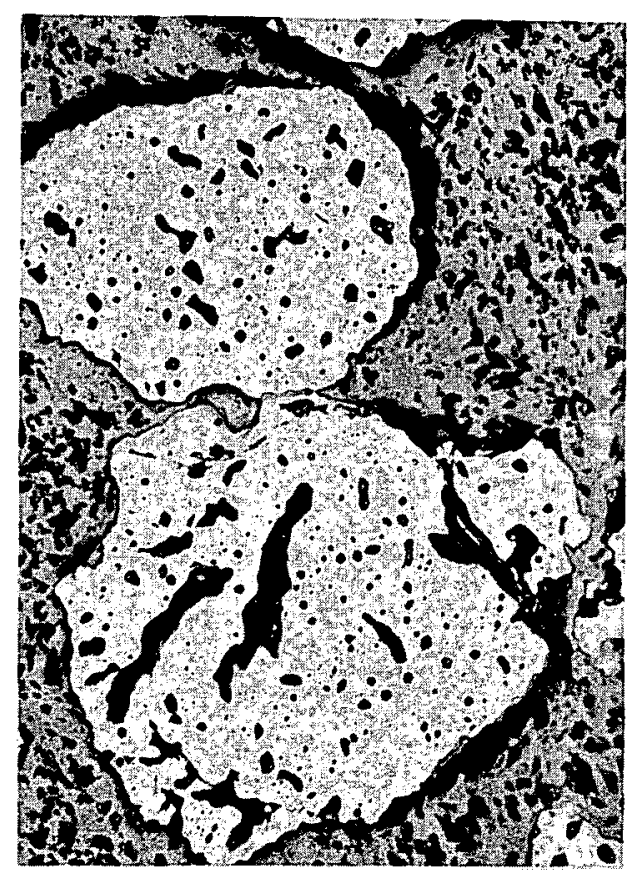

$M-754-2-2$

(b) As-polished cross section. (250x)

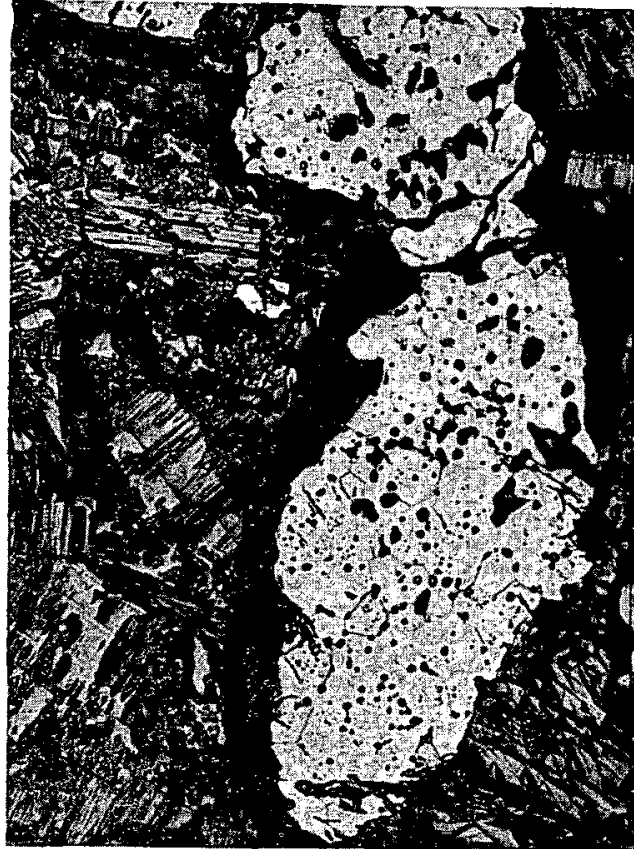

$M-754-2-5$ $100 \mu$

(c) Polished and etched cross section illustrating the $\mathrm{BeO}$ grain structure $(250 \times)$

Fig. 3--Pre-irradiation photomicrographs of typical coarse-particle $\mathrm{BeO}-30$ vol- $\% \mathrm{UO}_{2}$ fuel pellets used in the MGCR-9 capsule 
Table II

PRE - AND POST-IRRADIATION DENSITY OF FUEL SPECIMENS FROM THE MGCR-9 CAPSULE

\begin{tabular}{|c|c|c|c|c|c|c|}
\hline \multirow{2}{*}{$\begin{array}{c}\text { Specimen } \\
\text { No. }\end{array}$} & \multirow{2}{*}{$\begin{array}{l}\text { Pellet } \\
\text { No. }\end{array}$} & \multicolumn{2}{|c|}{$\begin{array}{c}\text { Pre-irradiation } \\
\text { Bulk Density }\end{array}$} & \multicolumn{2}{|c|}{$\begin{array}{c}\text { Post-irradiation } \\
\text { Bulk Density }\end{array}$} & \multirow{2}{*}{$\begin{array}{c}\text { Change } \\
\text { in Density } \\
(\%)\end{array}$} \\
\hline & & $\mathrm{g} / \mathrm{cm}^{3}$ & $\%$ Theo. & $\mathrm{g} / \mathrm{cm}^{3}$ & $\%$ Theo. & \\
\hline \multirow[t]{2}{*}{1} & F-106 & 5.16 & 95.6 & 4.93 & 91.3 & -4.5 \\
\hline & $F-107$ & 5.12 & 94.8 & 5.00 & 92.6 & -2.3 \\
\hline \multirow[t]{2}{*}{4} & $F-108$ & 5.21 & 96.5 & 5.03 & 93.1 & -3.5 \\
\hline & $F-109$ & 5.02 & 93.0 &.-- & --- & $\ldots$ \\
\hline \multirow[t]{2}{*}{2} & $F-110$ & 5.18 & 95.9 & --- & --- & $\cdot----$ \\
\hline & $F-111$ & 5.13 & 95.0 & --- & ---- & ---- \\
\hline \multirow[t]{2}{*}{3} & C - 124 & 5.05 & 93.5 & 4.80 & 88.9 & -4.5 \\
\hline & $C-125$ & 5.02 & 93.0 & --- & ---- & --- \\
\hline \multirow[t]{2}{*}{5} & $C-126$ & 5.04 & 93.3 & 4.91 & 90.8 & -2.4 \\
\hline & $C-127$ & 5.03 & 93.1 & ---- & --- & --- \\
\hline \multirow[t]{2}{*}{6} & $C-128$ & 5.06 & 93.7 & $-\ldots$ & ---- & ---- \\
\hline & $C-129$ & 5.02 & 93.0 & ---- & ---- & --- \\
\hline
\end{tabular}


DESCRIPTION OF THE IRRADIATION CAPSULE (MGCR - 9)

The capsule used in the irradiation of the fuel pellets was fabricated at Battelle Memorial Institute. The general features of this type of capsule have previously been described, ${ }^{6}$ although some of the details of the capsule construction were changed slightly for this irradiation. Figure 4 is a photograph of some of the components used in the construction of the capsule, and Fig. 5 is a cross-sectional view of the capsule through the region where the fuel pellets were located.

In this capsule the fuel specimens were clad with Hastelloy-X. Each of the Hastelloy-X fuel claddings was back-filled with helium prior to making the final weld closure. Two fuel pellets were contained in each compartment and comprised a single specimen. A total of six specimens were included in the capsule. The thermal bond between the Hastelloy-X fuel cladding and the inner capsule can was $\mathrm{NaK}$. Thermocouples were inserted in the $\mathrm{NaK}$ thermal bond with the hot junctions located adjacent to each fuel specimen in order to determine the temperatures that existed during the irradiation. An electrical resistance heater was brazed to the outside of the inner capsule can to provide a measure of control of the temperature in the capsule during the irradiation.

\section{EXPERIMENTAL PROCEDURE}

The capsule was designed for irradiation in the Materials Testing Reactor in position A-43-NW at a fuel-pellet surface temperature of approximately $1700^{\circ} \mathrm{F}$ and an estimated average fuel temperature of $2400^{\circ} \mathrm{F}$. This position received an estimated unperturbed thermal-neutron flux of approximately $5 \times 10^{13} \mathrm{nv}$. Physics calculations indicated that the effective flux in the fuel pellets was approximately $2 \times 10^{13} \mathrm{nv}$. The irradiation of the capsule began with MTR cycle No. 165 and continued for the equivalent of $7020 \mathrm{hr}$ at full reactor power. The capsule underwent a total of 89 thermal cycles during the irradiation. Of the original six thermocouples in the capsule, 


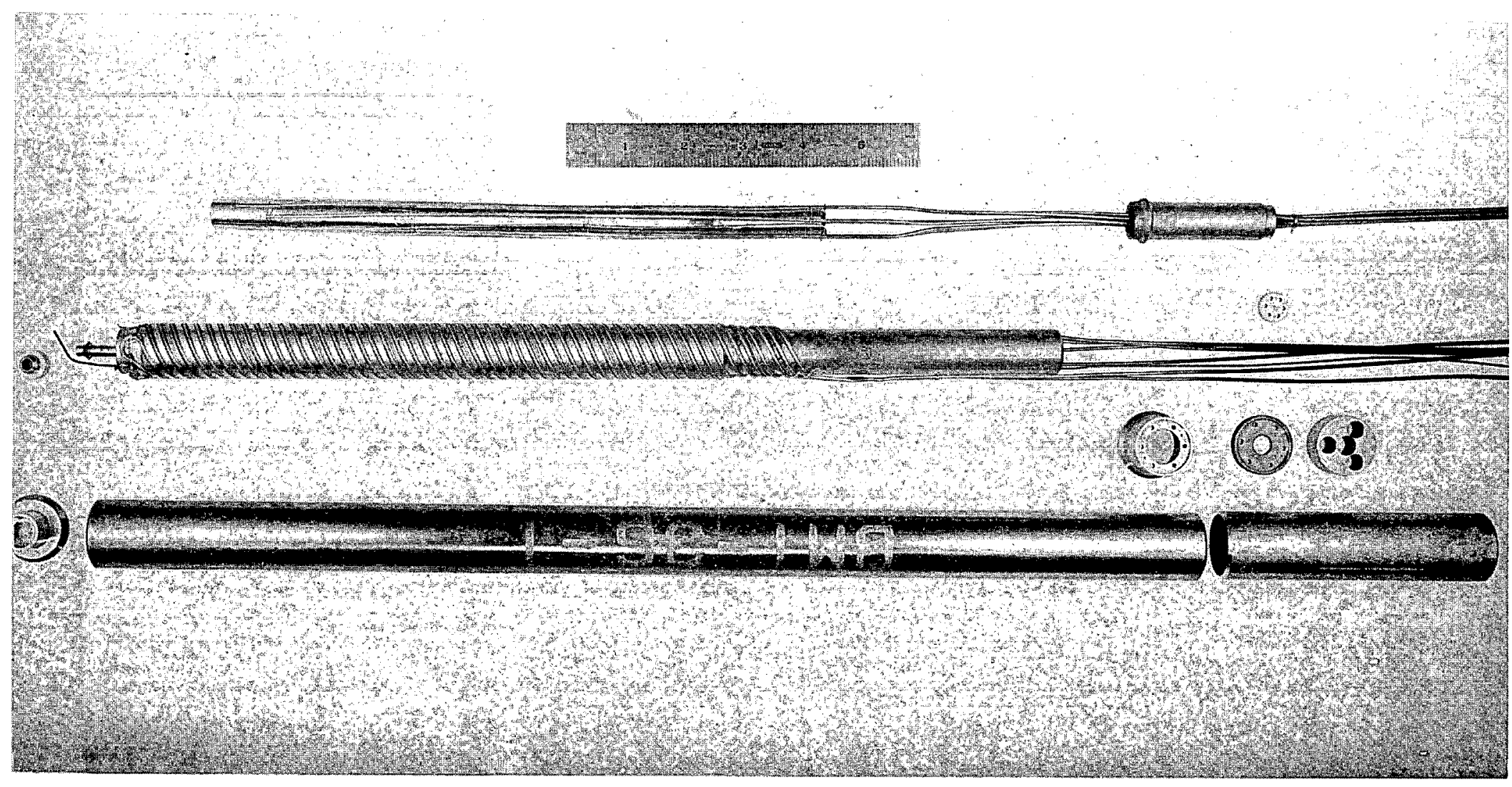

Fig. 4--Photograph of components used in the MGCR-9 capsule 


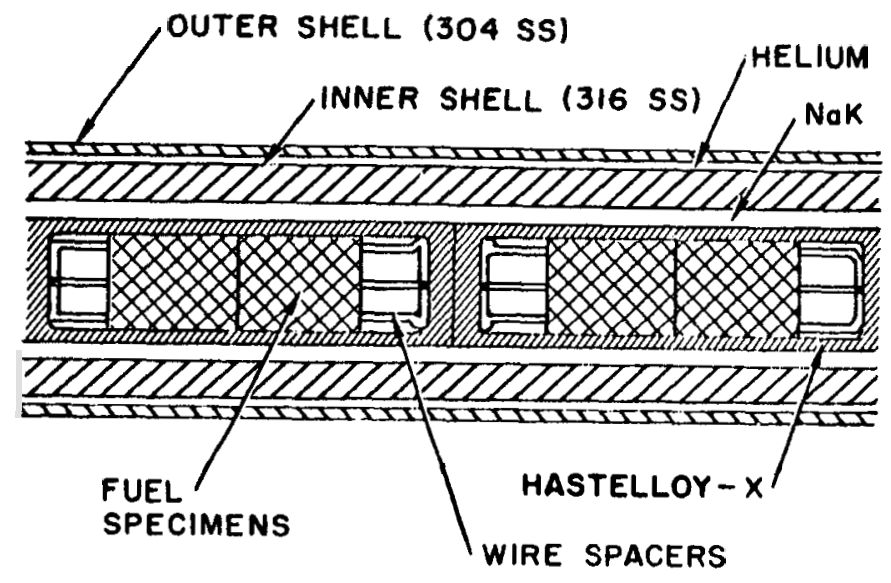

Fig. 5--Section of MGCR-9 capsule assembly (full scale) 
four continued to operate in a normal manner throughout the irradiation period, one became unreliable after six cycles of irradiation, and one became unreliable after eight cycles of irradiation. Electrical power to the resistance heater in the capsule was used throughout the irradiation as a shim control of the capsule temperature.

At the end of the irradiation period the capsule was shipped to the General Atomic hot cell where it was disassembled using conventional hotcell procedures. The densities of selected specimens were measured by a liquid-displacement technique. The fission gases that were generated inside the individual fuel claddings during the irradiation were collected and quantitatively analyzed using gamma-spectrometry techniques. Selected specimens were prepared for microscopic examination by normal polishing methods. Photomicrographs were taken using a Bausch and Lomb research metallograph that had been specially adapted for hot-cell use. The nickelcobalt dosimeters from the capsule were analyzed by radiochemical methods to determine the integrated neutron fluxes and the $U^{235}$ burnup in the capsule.

\section{RESULTS}

The results of the analysis of the fission gas released during the irradiation are presented in Table III. It was found that only one of the specimens containing fuel pellets with fine-dispersion $\mathrm{UO}_{2}$ released measurable quantities of $\mathrm{Kr}^{85}$. The fuel specimens containing coarse-particle $\mathrm{UO}_{2}$ released between $17 \%$ and $24 \%$ of the $\mathrm{Kr}^{85}$ during the irradiation. The amount of $\mathrm{Kr}^{85}$ released during irradiation is plotted in Fig. 6 as a function of specimen position in the capsule, fuel-particle size, and irradiation temperature.

Density changes observed for selected samples are presented in Table II and are plotted in Fig. 7 as a function of $\mathrm{UO}_{2}$ particle size, specimen position in the capsule, and total fission density in the individual specimens. Density changes in the range of $2.3 \%$ to $4.5 \%$ were observed for pellets 
Table III

FRAC TIONAL RELEASE OF $\mathrm{Kr}^{85}$

\begin{tabular}{c|l|c|c|c|c}
\hline $\begin{array}{c}\text { Specimen } \\
\text { No. }\end{array}$ & $\begin{array}{c}\text { Fuel- } \\
\text { particle } \\
\text { Size }\end{array}$ & $\begin{array}{c}\text { Fission } \\
\text { Density } \\
\left(\mathrm{f} / \mathrm{cm}^{3} \times 10^{-20}\right)\end{array}$ & $\begin{array}{c}\text { Total } \\
\text { Fissions } \\
\left(\times 10^{-20}\right)\end{array}$ & $\begin{array}{c}\mathrm{Kr} 85 \text { Atoms } \\
\text { Formed } \\
\left(\times 10^{-18}\right)\end{array}$ & $\begin{array}{c}\text { Fraction } \\
\text { Released }\end{array}$ \\
\hline 4 & Fine & 2.01 & 3.95 & 1.16 & N. D. a \\
1 & Fine & 2.19 & 4.35 & 1.27 & N. D. a \\
3 & Coarse & 2.28 & 4.42 & 1.30 & 0.242 \\
6 & Coarse & 2.28 & 4.40 & 1.29 & 0.176 \\
2 & Fine & 2.07 & 4.08 & 1.20 & 0.003 \\
5 & Coarse & 2.01 & 3.90 & 1.14 & 0.232 \\
\hline
\end{tabular}

$\underline{a}_{\text {None detected. }}$ 


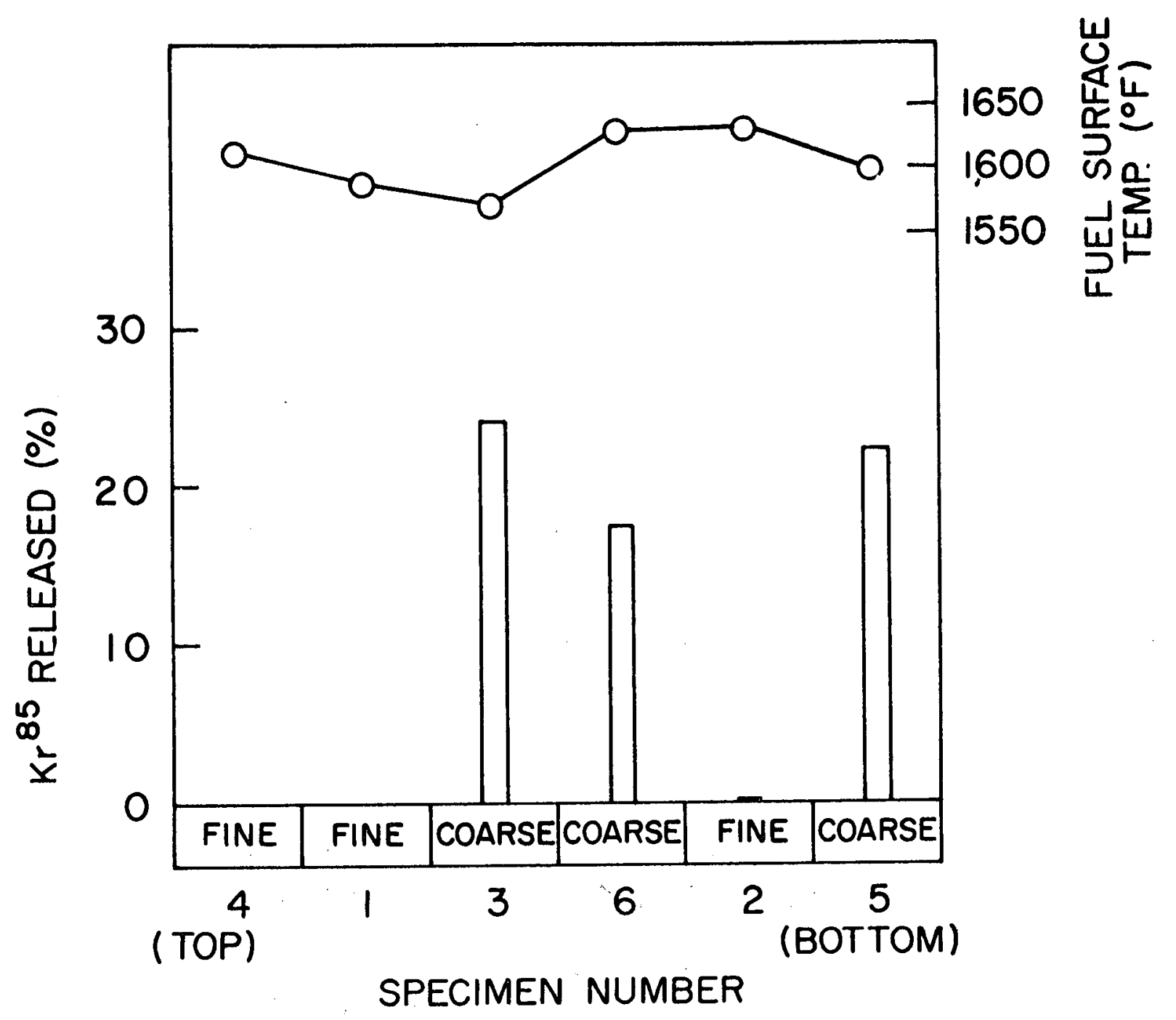

Fig. 6--Fission-gas release and fuel-surface temperature as a function of specimen position and fuel-particle size 


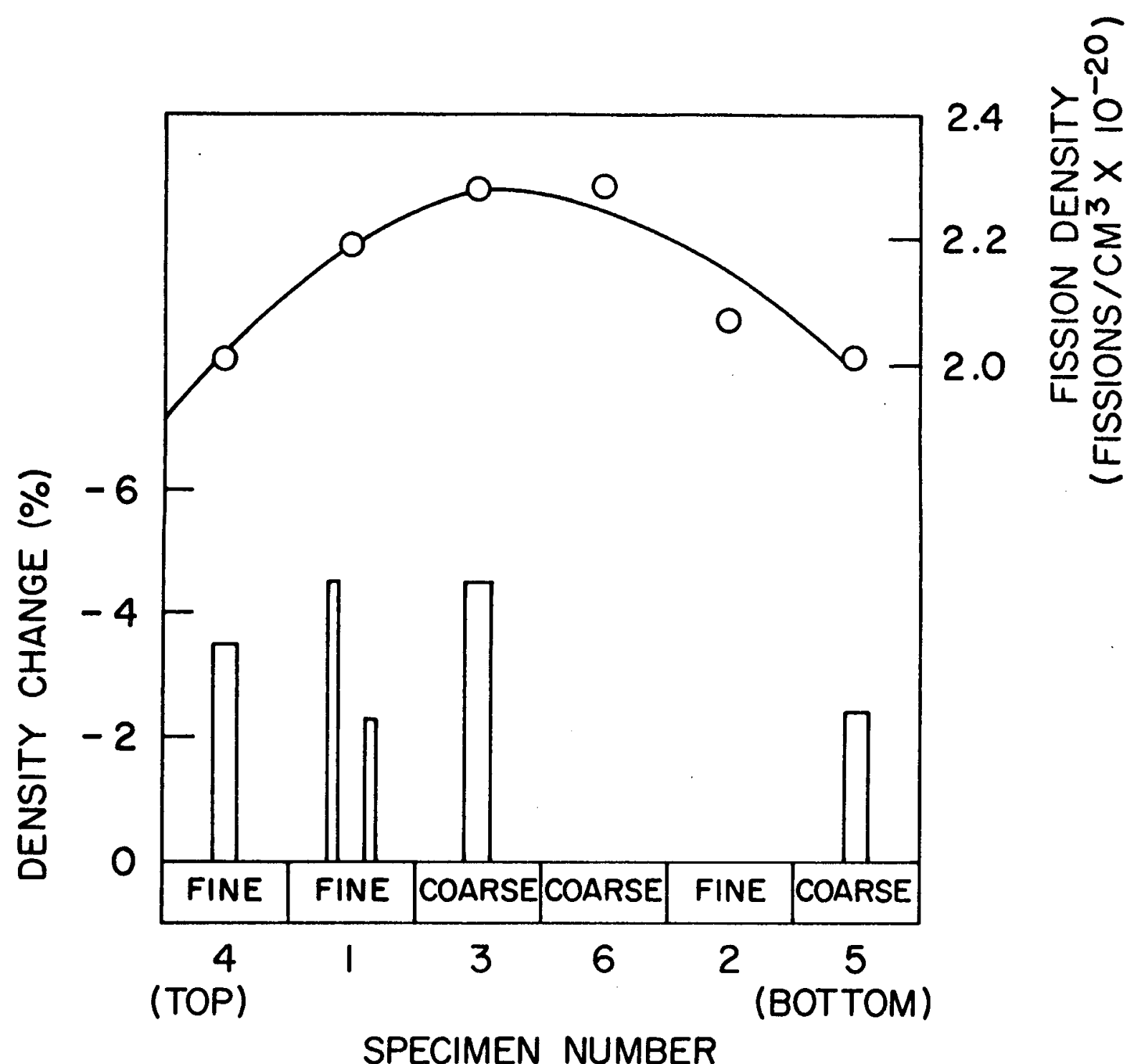

Fig. 7--Density change and irradiation flux as a function of specimen position and fuel-particle size 
containing both fine and coarse-particle fuel. The maximum fission density obtained in the capsule was $2.28 \times 10^{20}$ fissions $/ \mathrm{cm}^{3}$ (see Fig. 7 and Table IV).

Following the irradiation, photomacrographs of selected pellets were taken. Some of the results are presented in Fig. 8, where part (a) of the figure shows a fuel pellet in its Hastelloy-X cladding and parts (b) and (c) show two views of one of the fragments from the same fuel pellet. Photomicrographs illustrating the appearance of one of the $\mathrm{UO}_{2}$ particles and of the $\mathrm{BeO}$ matrix from a pellet containing the $\mathrm{UO}_{2}$ in the form of coarse particles are presented in Fig. 9. Similar photomicrographs for selected fine-particle fuel specimens are presented in Fig. 10.

\section{DISCUSSION}

The objective of this experiment was to provide some initial data on the relative performance of $\mathrm{BeO}-30$ vol-\% $\mathrm{UO}_{2}$ fuel bodies with the $\mathrm{UO}_{2}$ present in the form of fine $(<25 \mu)$ particles and coarse $(\sim 150 \mu)$ partictes. Results obtained by Yeniscavich and Bleiberg ${ }^{5}$ in a similar experiment where the fuels were irradiated at average temperatures below $1000^{\circ} \mathrm{F}$ indicated that the fine-particle fuels exhibited substantially larger dimensional change and fission-gas release than the coarse-particle fuels. In their experiment, the fuel loading was less than $30 \mathrm{wt}-\% \mathrm{UO}_{2}$ as compared with approximately $61 \mathrm{wt}-\% \mathrm{UO}_{2}$ in the present experiment. Yeniscavich and Bleibergobserved fission-gas releases as high as approximately $20 \%$ for the fine-particle fuels as compared with $7 \%$ fission-gas release for the coarse-particle fuel.

Dimensional-change data indicated even more marked differences in the performance of the two types of fuel material.

In some of the early fuel-irradiation work conducted at General Atomic as a part of the Experimental Beryllium Oxide Reactor Program, fuel pellets containing 20 vol- $\% \mathrm{UO}_{2}$ and having a density of approximately $89 \%$ of theoretical density released less than $0.5 \%$ of the $\mathrm{Kr}^{85}$ formed during the irradiation. 2 In that case the fuel-cladding surface temperature was 
Table IV

DOSIMETRY DATA FOR THE MGCR-9 CAPSULE

\begin{tabular}{c|l|c|c|c|c}
\hline $\begin{array}{c}\text { Specimen } \\
\text { No. }\end{array}$ & $\begin{array}{c}\text { Fuel- } \\
\text { particle } \\
\text { Size }\end{array}$ & $\begin{array}{c}\text { Fission } \\
\text { Density } \\
\left(\mathrm{f} / \mathrm{cm}^{3} \times 10^{-20}\right)\end{array}$ & $\begin{array}{c}\text { Total } \\
\text { Absorptions } \\
\text { in U235 } \\
\left(\times 10^{-20}\right)\end{array}$ & $\begin{array}{c}\text { Integrated } \\
\text { Fast Flux } \\
\left(\text { nvt } \times 10^{-20}\right. \\
>1 \text { Mev })\end{array}$ & $\begin{array}{c}\text { Integrated } \\
\text { Thermal Flux } \\
\left(\text { nvt } \times 10^{-20}\right)\end{array}$ \\
\hline 4 & Fine & 2.01 & 2.37 & 2.00 & 4.79 \\
1 & Fine & 2.19 & 2.58 & 2.24 & 5.22 \\
3 & Coarse & 2.28 & 2.69 & 2.36 & 5.46 \\
6 & Coarse & 2.28 & 2.68 & 2.36 & 5.42 \\
2 & Fine & 2.07 & 2.44 & 2.08 & 4.94 \\
5 & Coarse & 2.01 & 2.37 & 2.00 & 4.79 \\
\hline
\end{tabular}




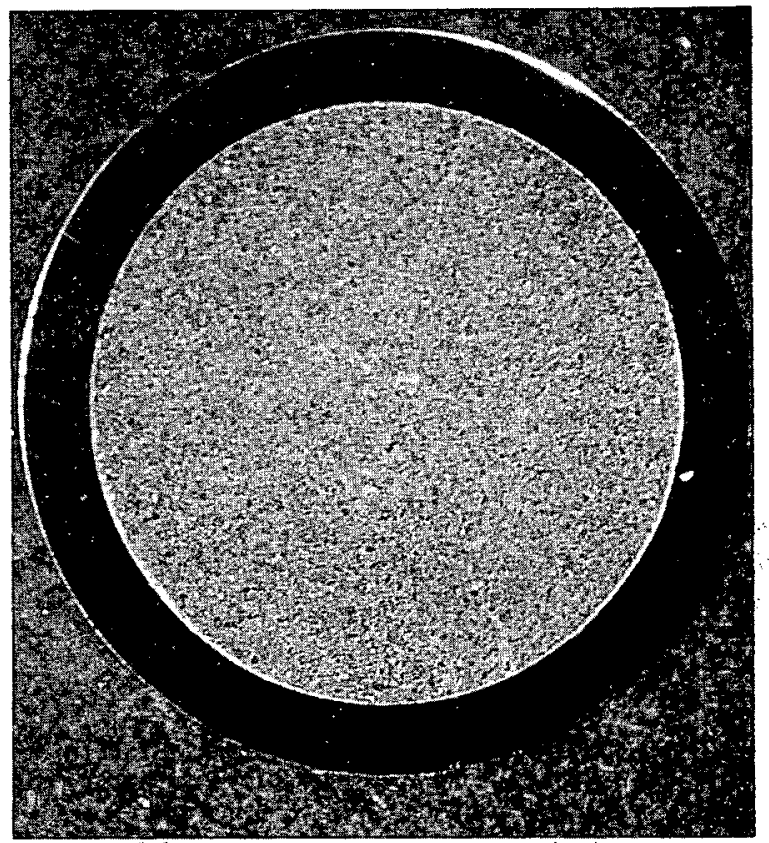

$M-1151$

(a) Irradiated $\mathrm{BeO}-30$ vol $-\% \mathrm{UO}_{2}$ fuel pellet as mounted and polished in its Hastelloy -X cladding $(6 \times)$

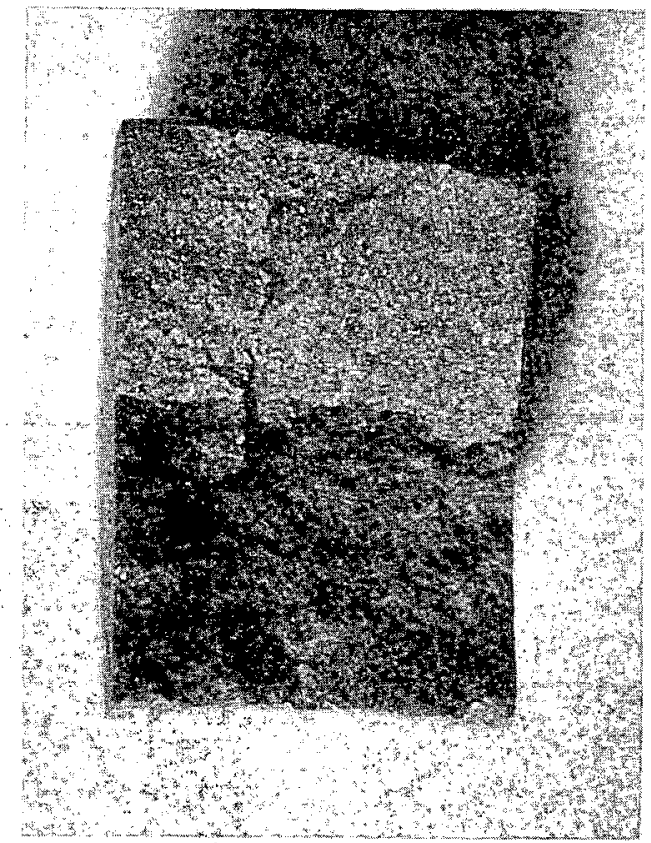

$M-1155$

(b) Fragment of an irradiated $\mathrm{BeO}-30$ vol $-\% \mathrm{UO}_{2}$ fuel pellet illustrating the nature of fracturing that occurred during irradiation $(6 \times)$

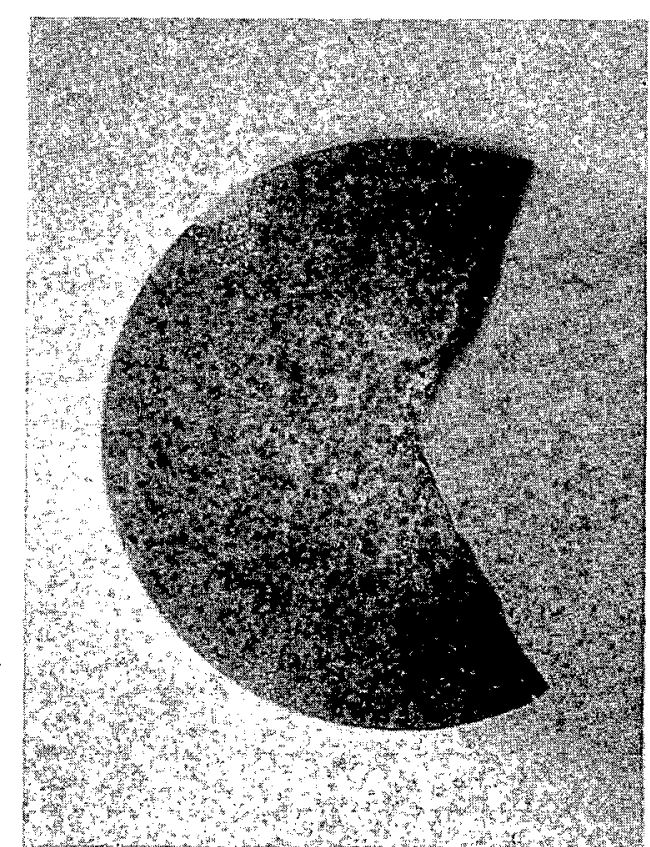

M-1 153

(c) End view of the fuel-pellet fragment shown in (b) at left $(6 x)$

Fig. 8--Photomacrographs of irradiated $\mathrm{BeO}-30$ vol- $\% \mathrm{UO}_{2}$ fuel pellets from the MGCR-9 capsule; fuel-particle size of $\sim 150 \mu$ 


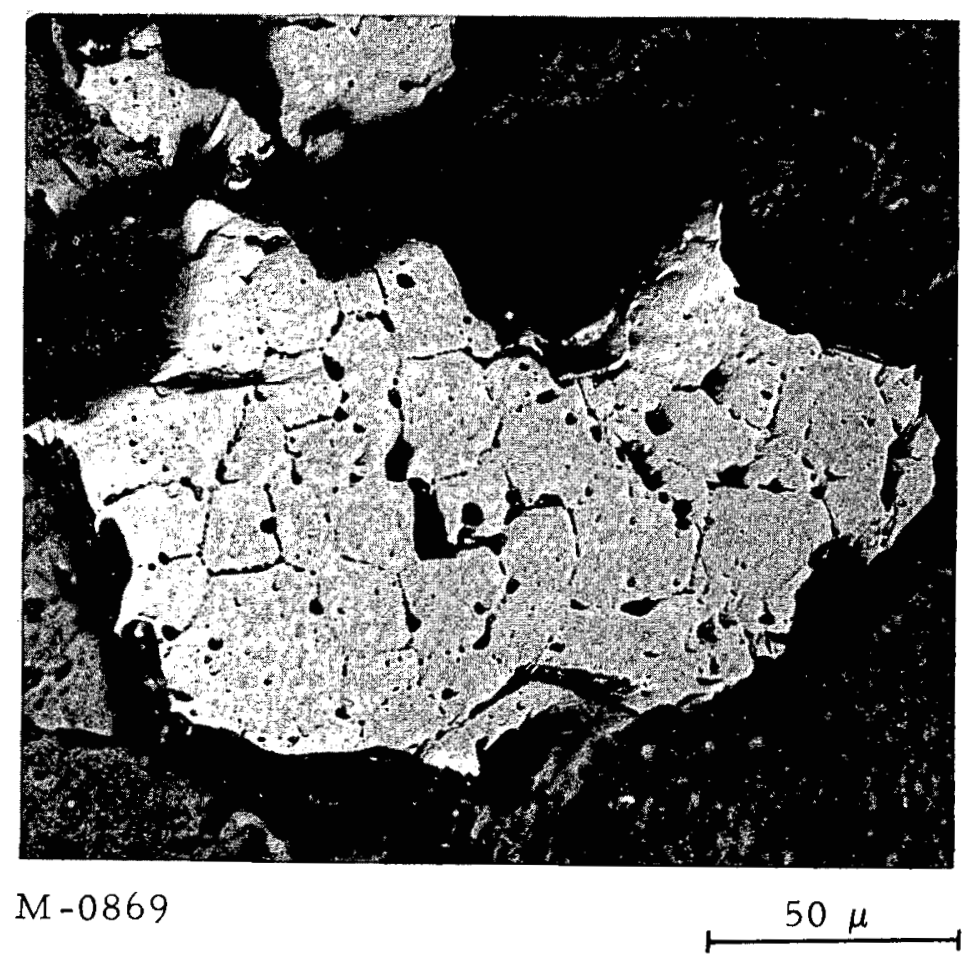

(a) As-polished pellet $(500 \times)$

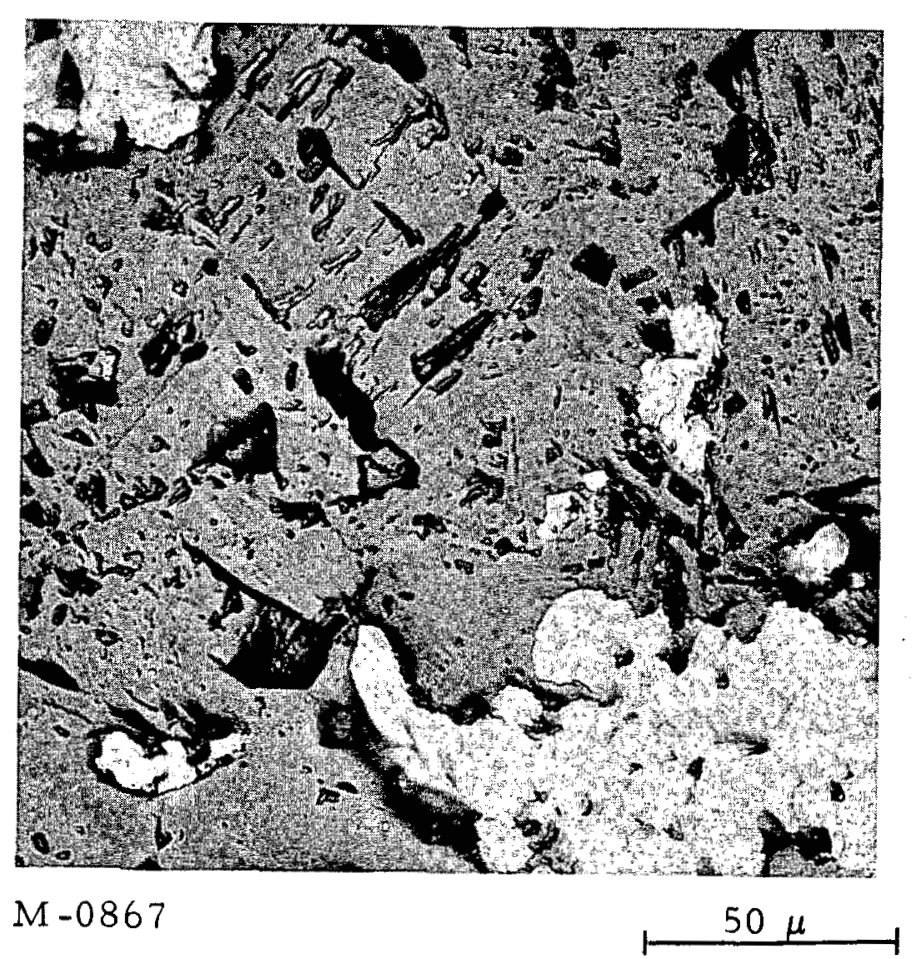

(b) Another area of the pellet shown at the left, illustrating the appearance of the BeO matrix (as-polished, 500x)

Fig. 9--Photomicrographs of a $\mathrm{BeO}-30$ vol-\% $\mathrm{UO}_{2}$ fuel pellet after irradiation to $\sim 2 \times 10^{20}$ fissions $/ \mathrm{cm}^{3}$; the $\mathrm{UO}_{2}$ was present as coarse $(\sim 150 \mu)$ particles 


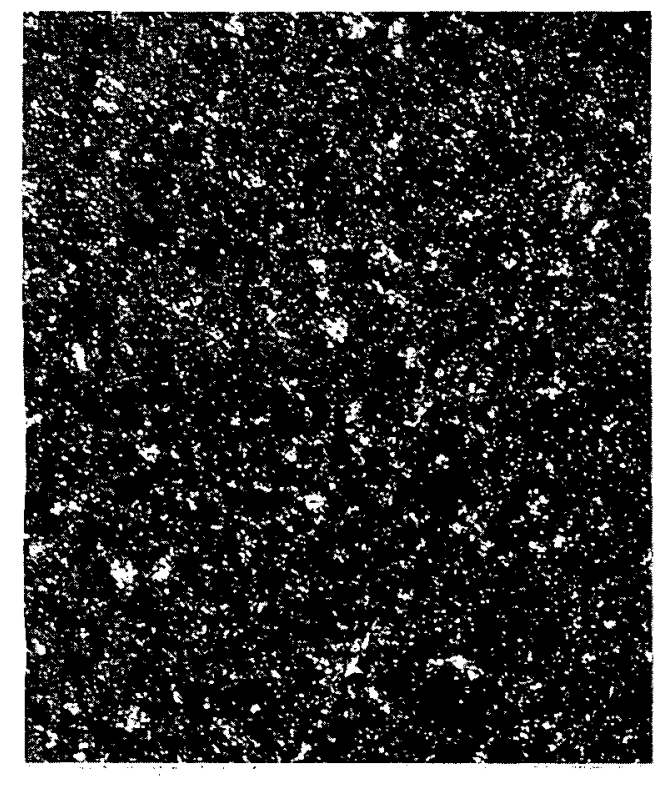

M-0864

(a) Unirradiated pellet $(250 x)$

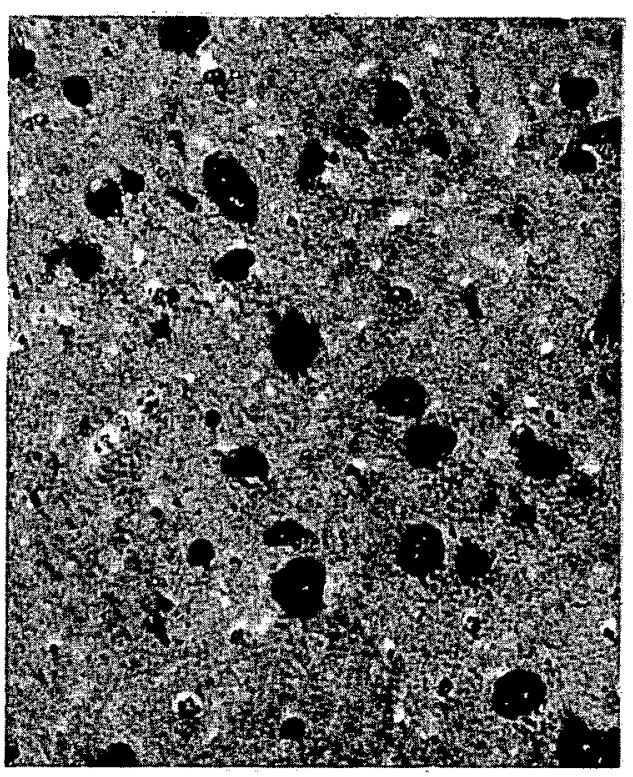

$\mathrm{M}-0890$

(b) As -polished irradiated pellet $(250 x)$

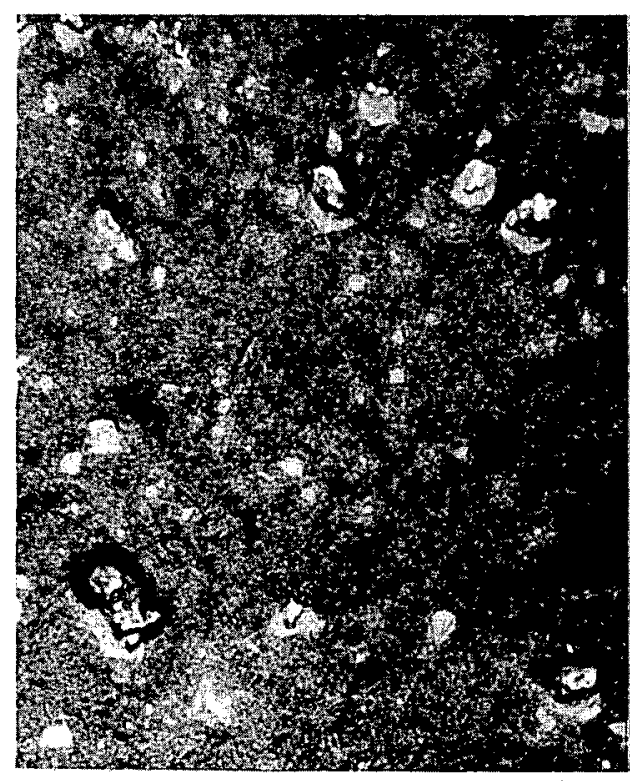

M-0897

$50 \mu$

(c) As -polished irradiated pellet $(500 x)$

Fig. 10--Photomicrographs of $\mathrm{BeO}-30$ vol-\% $\mathrm{UO}_{2}$ fuel pellets before and after irradiation to $\sim 2 \times 10^{20}$ fissions $/ \mathrm{cm}^{3}$; fine $(<25 \mu)$ fuel particles 
approximately $1550^{\circ} \mathrm{F}$, and the average fuel-pellet surface temperature was estimated to be in the range of $2000^{\circ}$ to $2300^{\circ} \mathrm{F}$. The UO 2 particles were present in the fuel bodies in the form of approximately 125- $\mu$ particles. More recent results obtained at General Atomic on the irradiation performance of $\mathrm{BeO}-\mathrm{UO}_{2}$ fuel pellets indicate excellent dimensional stability to high burnups of the uranium when the $\mathrm{UO}_{2}$ is present in the form of approximately 125- $\mu$ particles. As before, the fuel temperatures were estimated to be in the range of $2000^{\circ}$ to $2300^{\circ} \mathrm{F} .4$

The irradiation performance of $\mathrm{BeO}-\mathrm{UO}_{2}$ fuel pellets containing 70 and $80 \mathrm{wt}-\% \mathrm{UO}_{2}$ in the form of fine-particle dispersions has been reported by Titus and Saling. 7 They found that bodies containing both 70 and 80 wt- $\% \mathrm{UO}_{2}$ exhibited minor dimensional changes and, in general, a relatively small release of $\mathrm{Kr}^{85}(<3 \%)$. Of this gas release, approximately $0.25 \%$ could be accounted for on the basis of recoil.

In view of the results obtained previously at General Atomic and at other laboratories, the magnitude of the observed density changes and the quantities of $\mathrm{Kr}^{85}$ released in the present irradiation from the fuel specimens containing coarse-particle $\mathrm{UO}_{2}$ is surprising. While dimensional changes were not determined in the present irradiation experiment, they can be inferred from density measurements, and indicate linear dimensional increases of approximately 1.5\%. This dimensional behavior is in good agreement with results obtained in earlier irradiations at General Atomic and at other laboratories.

One of the objectives of using a material such as BeO as the matrix for reactor fuels is to provide a relatively impermeable path through which the fission products must migrate before they escape from the fuel bodies. Density-permeability relationships for $\mathrm{BeO}$ have been reported by British workers. ${ }^{8}$ In their study, it was found that a marked change in the permeability of $\mathrm{BeO}$ occurred at densities between $90 \%$ and $95 \%$ of theoretical density. Above $95 \%$ of theoretical density the BeO was very nearly impermeable to gases. In the present experiment, the starting densities of the fuel pellets 
were $94 \%$ to $95 \%$ of theoretical density. These values decreased to approximately $90 \%$ of theoretical density in some cases during the irradiation. Fuel pellets containing fine-particle $\mathrm{UO}_{2}$ and fuel pellets containing coarse-particle $\mathrm{UO}_{2}$ exhibited similar changes in density. In view of the measured gaspermeability-density relationship for $\mathrm{BeO}$, the observed fission-gas release behavior for the two kinds of fuels irradiated in this experiment does not appear to be consistent.

A comparison of the microstructure of the irradiated pellets with that of unirradiated pellets indicates that for the fine-particle $\mathrm{UO}_{2}$ material, some agglomeration of the $\mathrm{UO}_{2}$ particles appears to have occurred during irradiation. In general, the appearance of the fine-particle $\mathrm{UO}_{2}$ materials from this experiment is very similar to that reported for $\mathrm{UO}_{2}$ by Titus and Saling. 7 No marked change in the structure of the BeO was observed. For the fuel pellets containing the $\mathrm{UO}_{2}$ in the form of both coarse and fine particles, it was observed that many $\mathrm{UO}_{2}$ particles were removed from the matrixduring the polishing operation. Furthermore, pieces of material appeared to have been pulled out of the sample from the region of the boundary between the $\mathrm{UO}_{2}$ particles and the BeO matrix. Examples of this behavior, which was rather pronounced, are illustrated in Figs. 9 and 10. A comparison of the structure of the $\mathrm{BeO}$ from the irradiated pellets with that of the $\mathrm{BeO}$ in the pellets before the irradiation may be made by referring to Figs. 2, 9, and 10. The occurrence of extensive grain-boundary separation such as that reported ${ }^{9}$ to occur in $\mathrm{BeO}$ during low-temperature irradiation was not observed by optical-microscopy techniques: (Electron-microscopy examination of the pellets has not been performed.) On the basis of results from the optical examination of the microstructure of the BeO, it does not appear that marked changes occurred during the irradiation.

\section{SUMMARY AND CONCLUSIONS}

The results of the irradiation experiment may be summarized as follows: 1. Fuel pellets composed of $\mathrm{BeO}-30$ vol-\% $\mathrm{UO}_{2}$ wer $\epsilon$ irradiated to 
integrated exposures of approximately $2 \times 10^{20}$ fissions $/ \mathrm{cm}^{3}$. Fuel pellets containing the $\mathrm{UO}_{2}$ as fine $(<25 \mu)$ particles and coarse $(\sim 150 \mu)$ particles were included in the experiment. The estimated fuel-surface temperatures were approximately $1700^{\circ} \mathrm{F}$.

2. As inferred from the results of density measurements, the dimensional changes in the pellets did not appear to vary as a function of $\mathrm{UO}_{2}$ particle size, and represented an increase of the order of $1 \%$ to $1.5 \%$.

3. Measurements of the quantity of $\mathrm{Kr}^{85}$ fission gas that was collected inside the metallic fuel-pellet claddings during the irradiation indicated that approximately $1 \%$ of the $\mathrm{Kr}^{85}$ was released from fuel pellets containing fineparticle $\mathrm{UO}_{2}$, while approximately $20 \%$ of the $\mathrm{Kr}^{85}$ was released from fuel pellets containing coarse-particle $\mathrm{UO}_{2}$.

4. Major changes were not observed in the microstructure of either type of fuel pellet included in the test. Pull-out in the neighborhood of the fuel particles during the preparation of specimens for microscopic examination appeared to be more pronounced as a result of the irradiation.

The conclusions reached from this irradiation experiment are:

1. The results obtained on fission-gas release from the two different types of fuel tested do not appear to agree with results obtained in previous irradiation experiments at several laboratories or with the results that would be predicted on the basis of theory.

2. Changes that occurred in the density and microstructure of the $\mathrm{BeO}-\mathrm{UO}_{2}$ fuel pellets during irradiation indicate that the performance of such pellets should be satisfactory for EBOR-type applications.

3. Additional experiments are required to obtain information that will assist in developing an explanation for the fission-gas release behavior that was observed in the present experiment. In this connection, it should be noted that a second capsule containing similar fuel pellets was irradiated in the Materials Testing Reactor to an exposure approximately $1-1 / 2$ times that obtained in this irradiation experiment, and that the examination of specimens from the second capsule is presently under way in the General Atomic hot cell. 


\section{REFERENCES}

1. C. E. Weber, "Progress in Dispersion Elements, "Progress In Nuclear Energy, Series V, Vol. 2, Metallurgy and Fuels, Pergamon Press, New York, 1959, pp. 295-362.

2. M. T. Simnad and W. P. Wallace, "Materials and Fuel Element Development for the MGCR and HTGR Helium-cooled Reactors, A Review, "General Atomic Report GA-1265, February 25, 1960.

3. B. S. Hickman, "Irradiation Damage Aspects of Dispersion Fuel Elements for the H.T.G.C. Reactor," Australian Atomic Energy Commission Research Establishment, Report AAEC/TM 139, June, 1962.

4. D. E. Johnson and F. H. Lofftus, "The Fabrication and Irradiation Testing of Dispersion-Type BeO-UO 2 Ceramic Fuel Materials, "General Atomic Report GA-3483, October 10, 1962.

5. W. Yeniscavich and M。 L. Bleiberg, "The Effects of Irradiation on $\mathrm{BeO}+\mathrm{UO}_{2}, \mathrm{ThO}_{2}+\mathrm{UO}_{2}$, and $\mathrm{ZrO}_{2}+\mathrm{CaO}+\mathrm{UO}_{2}$, "Bettis Atomic Power Laboratory Report WAPD-BT-20, September, 1960, pp. 1-22.

6. D. E. Johnson, 'Stability of $\mathrm{BeO}-\mathrm{UO}_{2}$ Reactor Fuel Material During Irradiation," General Atomic Report GA-2065, March 31, 1961.

7. G. W. Titus and J. H. Saling, "High Temperature Irradiation of $\mathrm{UO}_{2}-\mathrm{BeO}$ Bodies, "Aerojet - General Nucleonics Report IDO-28600, January, 1963.

8. J. S. O'Neill, A. W. Hey, and D。T. Livey, "Density and Permeability Relationships in Fabricated Beryllia, "Atomic Energy Research Establishment Report AERE-R-3007, July, 1959.

9. "First Annual Report - High Temperature Materials and Reactor Component Development Programs, "General Electric Company Report GEMP-106A, February 28, 1962, p. 90。 